\title{
Selectin adhesion molecules in Behçet's disease
}

Seminur Haznedaroğlu, Yaşar Karaaslan, Yahya Büyükaşı, Ali Koşar, Osman İ Özcebe, İbrahim C Haznedaroğlu, Şerafettin Kirazlı, Semra V Dündar

\begin{abstract}
Objectives-The pathogenesis of Behçet's disease (BD) is closely related to endothelial cells, leucocyte functions and autoimmunity. The aim of this study was to investigate circulating selectin adhesion molecules, which are known to play a significant part in the immune response especially by regulating interactions of the leucocytes with endothelium, in BD.

Methods-Plasma E-, L-, and P-selectin concentrations were evaluated in 11 patients with widespread BD (group I), 10 cases with merely mucocutaneous involvement (group II) and 15 age and sex matched healthy control subjects. The patients were newly or previously diagnosed cases not taking any drug for BD.

Results-Plasma concentrations of all selectins were significantly higher in group I compared with group II. E-selectin and $P$-selectin were significantly increased in each subgroup of patients compared with the healthy controls. L-selectin concentrations were higher than the controls only in group I.

Conclusions-Increases in the selectins in BD may be a direct consequence of the leucocyte, endothelium and platelet activations observed during the disease process. However, abnormal/increased selectin expression to various triggers should also be considered. More prominent increases in patients with extensive disease suggest that circulating selectin concentrations are related to disease severity.

(Ann Rheum Dis 2000;59:61-63)
\end{abstract}

Fatih University Medical School, Department of Rheumatology, Ankara, Turkey Ş Haznedaroğlu

Y Karaaslan

Hacettepe University Medical School, Department of Hematology, Ankara, Turkey

Y Büyükaşık

A Koşar

O İ Özcebe

İ C Haznedaroğlu

Ş Kirazlı

S V Dündar

Correspondence to: Dr S Haznedaroğlu, 36 Sok Sun Apt No 3/2, TR-06490 Bahçelievler Ankara, Turkey

Accepted for publication 8 September 1999 phenomenon in $\mathrm{BD}^{1}{ }^{15-7}$ Soluble mediato the inflammation (for example, tumour necrosis factor $\alpha$, interferon $\gamma$ and interleukin 1) are well known inducers of adhesion molecule expression. ${ }^{8}$ The pathobiology of $\mathrm{BD}$ may be related to the selectins, because it is an inflammatory process in which leucocyte and endothelial abnormalities and autoimmunity are possibly involved. The aim of this study was to investigate plasma concentrations of the selectins in patients with BD and to search for a possible relation between disease severity and the selectin concentrations.

\section{Methods}

In an outpatient setting, consecutive BD patients with widespread disease (that is, active systemic and mucocutaneous involvements) were selected for assessment of plasma selectin concentrations (table 1). Selectin concentrations of these patients (group I) (M/F 4/7; mean (SD) age 32 (11); range 20-54 years) were compared with the concentrations of a second group of consecutive $\mathrm{BD}$ patients (group II) (M/F 5/5; mean age 37 (11); range 25-53 years) who had only mucocutaneous disease and to the concentrations of age and sex matched healthy volunteers $(\mathrm{M} / \mathrm{F}=6 / 9$; mean age 31.3 (5.5); range $25-44$ years). The patients were required to be newly diagnosed or previously recognised cases not taking any drug for BD. All patients were or had been diagnosed according to the criteria of the International Study Group for BD. They were referred to an ophthalmologist to be evaluated for eye involvement. The majority of the control subjects were department staff.

Blood samples were taken before any treatment for BD was started. Peripheral venous blood samples were taken between 8 and 10 am into $3.8 \% \quad 1: 9$ trisodium citrate containing vacuum tubes without venous occlusion. The blood samples were centrifuged immediately at $2000 \mathrm{~g}$ for 15 minutes and then the plasmas were stored in several aliquotes at $-70^{\circ} \mathrm{C}$ until assayed. Plasma E- selectin (Parameter Human E-selectin Immunoassay, R\&D Systems Europe, Abingdon, UK), P-selectin (sP-selectin enzyme linked immunosorbent assay (ELISA), Bender MedSystems, Vienna, Austria) and L-selectin (sL-selectin ELISA, Bender MedSystems, Vienna, Austria) levels were measured by sandwich type ELISA. The intraassay coefficient of variation was $6 \%$, the interassay coefficient of variation $8 \%$, computed from results of pathological plasma samples in our laboratory.

Plasma selectin concentrations between patient subgroups and controls were compared with the Mann-Whitney U test. Statistical significance was assigned to $\mathrm{p}$ values lower than 0.05 . 
Table 1 Clinical characteristics and selectin concentrations of individual patients at the time of blood sampling. The first 11 patients (group I) had widespread involvement. The remaining cases had only mucocutaneous disease (group II). Numbers of aphtae and locations of uveitis, arthritis and thrombosis are presented in parentheses

\begin{tabular}{|c|c|c|c|c|c|c|c|c|c|c|c|}
\hline & \multirow{2}{*}{$\begin{array}{l}\text { Oral } \\
\text { aphtae }\end{array}$} & \multirow{2}{*}{$\begin{array}{l}\text { Genital } \\
\text { aphtae }\end{array}$} & \multirow[b]{2}{*}{ Pathergy } & \multirow[b]{2}{*}{ Folliculitis } & \multirow[b]{2}{*}{$E N$} & \multirow[b]{2}{*}{ Uveitis } & \multirow[b]{2}{*}{ Arthritis } & \multirow[b]{2}{*}{$V T$} & \multicolumn{3}{|c|}{ Selectins ( $\mathrm{ng} / \mathrm{ml}$ ) } \\
\hline & & & & & & & & & $E-$ & $L-$ & $P-$ \\
\hline 1 & - & - & + & + & - & - & $+_{(\text {knee monoarthritis) }}$ & - & 39 & 875 & 713 \\
\hline 2 & - & - & - & + & - & - & $+t_{\text {(bilat. knee) }}$ & - & 89 & 1115 & 612 \\
\hline 3 & + & - & - & - & + & - & _ & + & 156 & 1214 & 811 \\
\hline 4 & $+_{(1)}^{(1)}$ & - & + & - & - & $+_{\text {(anterior) }}$ & - & - $^{\text {(popital) }}$ & 51 & 715 & 269 \\
\hline 5 & - & - & + & + & - & - $^{\text {(anterior) }}$ & - & $+_{\text {(superficial femoral) }}$ & 108 & 1785 & 1305 \\
\hline 6 & - & - & + & - & - & - & - & + & 152 & 1318 & 627 \\
\hline 7 & - & - & + & - & - & - & $t_{(\text {knee monoarthritis })}$ & - & 121 & 1315 & 720 \\
\hline 8 & $+_{(1)}$ & $+_{(1)}$ & - & - & - & $+_{\text {(bilat. anterior) }}$ & _(knee monoarthritis) & - & 107 & 820 & 754 \\
\hline 9 & - & $+(1)$ & - & + & - & _ (bilat. anterior) & - & $+_{(\text {poplital })}$ & 41 & 1290 & 725 \\
\hline 10 & $+_{(1)}$ & - & + & + & - & - & $\boldsymbol{t}_{\text {(ankle monoarthritis) }}$ & - $^{\text {(poplital) }}$ & 107 & 1200 & 1625 \\
\hline 11 & - & - & + & - & - & $+_{\text {(anterior) }}$ & - & - & 157 & 526 & 820 \\
\hline 12 & + & - & - & - & - & - (anterior) & - & - & 50 & 510 & 240 \\
\hline 13 & - & + & + & - & - & - & - & - & 18 & 386 & 185 \\
\hline 14 & - & - & + & - & - & - & - & - & 80 & 780 & 315 \\
\hline 15 & - & - & + & + & - & - & - & - & 45 & 525 & 219 \\
\hline 16 & $+_{(1)}$ & - & + & - & - & - & - & - & 86 & 810 & 779 \\
\hline 17 & $+(1)$ & - & - & - & - & - & - & - & 47 & 525 & 480 \\
\hline 18 & - & - & + & + & - & - & - & - & 86 & 804 & 278 \\
\hline 19 & $t_{(2)}$ & - & - & - & - & - & - & - & 80 & 705 & 320 \\
\hline 20 & $+_{(1)}^{(2)}$ & - & - & - & - & - & - & - & 42 & 478 & 375 \\
\hline 21 & $+t_{(2)}$ & - & - & + & - & - & - & - & 19 & 315 & 524 \\
\hline
\end{tabular}

$\mathrm{EN}=$ erythema nodosum; $\mathrm{VT}=$ venous thrombosis

\section{Results}

Plasma concentrations of all selectins were significantly higher in group I compared with group II (tables 1 and 2). Taken together, the patients with BD had significantly higher Eand P-selectin concentrations compared with the control group (table 2). L-selectin concentrations were also higher in the patients, but the difference was not statistically significant. Eand P-selectin concentrations were significantly increased in each subgroup of the patients compared with the control subjects. L-selectin concentrations were higher than the control group in group I, but not in group II.

\section{Discussion}

Focal neutrophil infiltration is an essential histopathological feature of BD. ${ }^{1}$ The pathergy reaction, histologically described as appearance of a sterile microabscess in the site of skin prick, is a clinical reflection of the non-specific neutrophil hyperactivity of BD. ${ }^{9}$ Endothelial injury and/or pathological activation, another characteristic of BD, can be observed even in patients without any clinical vascular involvement. ${ }^{11}{ }^{11}$ High frequency of venous thromboembolism in $\mathrm{BD}$ suggests that the endothelial injury seen in these patients may have unique properties leading to thrombotic tendency. ${ }^{11} 12$ Platelet hyperactivity in relation to pathological eicosanoid pathway has also been suggested to occur in patients with BD. ${ }^{13} 14$

P-, E-, and L-selectins are the members of selectin adhesion molecule family. ${ }^{3}$ E-selectin is expressed by activated endothelial cells.

Table 2 Plasma selectin concentrations in the patients with Behçet's disease and healthy control subjects

\begin{tabular}{lllll}
\hline & $\begin{array}{l}\text { All patients } \\
(n=21)\end{array}$ & Group I $(n=11)$ & Group II $(n=10)$ & $\begin{array}{l}\text { Controls } \\
(n=15)\end{array}$ \\
\hline P-selectin $(\mathrm{ng} / \mathrm{ml})$ & $612(471)^{\star}$ & $725(193)^{\star}$ & $317(255)^{\star} \|$ & $185(74)$ \\
E-selectin $(\mathrm{ng} / \mathrm{ml})$ & $80(64)^{\star}$ & $107(101)^{\star}$ & $48(45) \ddagger^{\mathrm{a}}$ & $29(22)$ \\
L-selectin $(\mathrm{ng} / \mathrm{ml})$ & $804(682) \dagger$ & $1200(495)^{\star}$ & $525(331) \S^{\mathrm{b}}$ & $605(230)$ \\
\hline
\end{tabular}

All values are median with the interquartile range in parentheses. ${ }^{*} \mathrm{p}<0.001 v$ control group, $\dagger \mathrm{p}=0.065 v$ control group, $\neq \mathrm{p}<0.05 v$ control group, $\Omega \mathrm{p}>0.05 v$ control group, $\| \mathrm{p}<0.01 v$ group $\mathrm{I},{ }^{\mathrm{a}} \mathrm{p}<0.05 v$ group I, ${ }^{\mathrm{b}} \mathrm{p}<0.001 v$ group I.
P-selectin is constitutively synthesised and stored within the $\alpha$ granules of platelets and Weibel-Palade bodies of the endothelial cells and is redistributed to the plasma membrane upon activation of these cells. L-selectin is expressed on the surface of most leucocytes. Because the selectin adhesion molecules are shed from activated cells, soluble forms of these proteins can be used as activation markers of endothelium (E-selectin and perhaps P-selectin), ${ }^{15}$ platelets (P-selectin),${ }^{16}$ and leucocytes (L-selectin). ${ }^{17}$ The main role of the selectin adhesion molecules is closely related to the immunological response: regulation of leucocyte trafficking and supporting leucocyte rolling. ${ }^{3}$ P-selectin has also specific roles in the inflammatory and haemostatic functions of the platelets. $^{34}$ At the site of inflammation, endothelial cells are subjected to prolonged or repeated stimulation by many chemical mediators. Re-expression of functional P-selectin molecules on the endothelial cell surface by repeated stimulation with thrombin was shown. ${ }^{18}$ Increased plasma thrombinantithrombin III complex and prothrombin fragment $_{1+2}$ concentrations, which reflect intravascular thrombin generation in the prethrombotic state of $\mathrm{BD}$ have also been demonstrated. ${ }^{11} 19$ The association and pathophysiological relevance of the increased circulating thrombin and P-selectin molecules during the pathological transition of Behçet endothelium remains to be elucidated.

In this study, we found that P- and E-selectin concentrations were increased in patients with BD compared with the healthy control subjects. L-selectin concentration was higher than the controls only in patients with widespread involvement. Plasma concentrations of the selectins were more prominently increased in $\mathrm{BD}$ patients with widespread involvement compared with those with only mucocutaneous disease. Increase of the selectins in BD reflects activation of the leucocytes and platelets, and injury/activation of the endothelium in these patients. More prominent increases in patients 
with systemic involvement suggest that these activations are associated with disease severity.

Increments of the selectin concentrations in BD may be simply a result of the leucocyte, endothelium and platelet activations related to the inflammatory process and/or haemostatic activation observed in these patients. However, a primary abnormality in selectin expression/ secretion mechanisms should also be considered as a possible cause of the increased selectin concentrations. Non-specifically increased neutrophil migration attributable to abnormal/ increased selectin expression of the blood cells and/or endothelium should be investigated as a possible pathogenetic mechanism in BD.

Colchicine has been shown to change quantitative and qualitative display of selectins on endothelial cells and neutrophils. ${ }^{20}$ Specifically, it has been suggested that colchicine may exert its prophylactic effects on cytokine provoked inflammation by diminishing the qualitative expression of E-selectin on endothelium, and its therapeutic effects by diminishing the quantitative expression of L-selectin on neutrophils. Therapeutic effect of this agent in BD should rise the possibility of a selectin dependent mechanism in the pathogenesis of BD. Definitive roles of the selectin adhesion molecules in the aetiopathogenesis of the disease, and their modulation with the established treatment modalities are important issues that certainly deserve further elucidation.

1 Kaklamani VG, Vaiopoulos G, Kaklamanis PG. Behçet's disease. Semin Arthritis Rheum 1998;27:197-217.

2 Yazici $H$. The place of Behçet's syndrome among the autoimmune diseases. Int Rev Immunol 1997;14:1-10.

3 Kansas GS. Selectins and their ligands: current concepts and controversies. Blood 1996;88:3259-87.

4 Palabrica T, Lobb R, Furie BC, Aronovitz M, Benjamin C, Hsu YM, et al. Leukocyte accumulation promoting fibrin deposition is mediated in vivo by P-selectin on adherent platelets. Nature 1992;359:848-51.
5 Djawari D, Hornstein OP, Luckner L. Skin window examination according to Rebuck and cutaneous pathergy tests in patients with Behçet's disease. Dermatologica 1985;170: in patien $265-70$.

6 Sobel JD, Haim S, Obedeanu N, Meshulam T, Merzbach D. Polymorphonuclear leucocyte function in Behçet's disease. J Clin Pathol 1977;30:250-3.

7 Carletto A, Pacor ML, Biasi D, Caramaschi P, Zeminian S, Bellavite $\mathrm{P}$, et al. Changes of neutrophil migration without modification of in vitro metabolism and adhesion in modification of in vitro metabolism and adhease. J Rheumatol 1997;24:1332-6.

8 McMurray RW. Adhesion molecules in autoimmune disease. Semin Arthritis Rheum 1996;25:215-33

9 Gül A, Esin S, Dilsen N, Konice M, Wigzell H, Biberfeld P. Immunohistology of skin pathergy reaction in Behcet's disease. Br J Dermatol 1995;132:901-7.

10 Haznedaroglu IC, Özdemir O, Özcebe O, Dündar SV, Kirazli S. Circulating thrombomodulin as a clue of endothelial damage in Behçet's disease. Thromb Haemost 1996;75: 974-5.

11 Haznedaroglu IC, Özcebe O, Özdemir O, Çelik I, Dündar SV, Kirazli S. Impaired haemostatic kinetics and endothelial function in Behçet's disease. J Intern Med 1996;240: $181-7$.

12 Haznedaroglu IC, Büyükasik Y, Özdemir O, Özcebe OI, Dündar SV, Kirazli S. The prethrombotic/hypercoagulable state of Behçet's disease. [Comment on the article by Golden et al]. Arthritis Rheum 1997;40:1915-16.

13 Wilson AP, Efthimiou J, Betteridge DJ. Decreased prostacyclin sensitivity of platelets in patients with Behçet's syndrome. Eur J Clin Invest 1988;18:410-14.

14 Haznedaroglu IC, Dündar SV, Kirazli S. Eicosanoids in the prethrombotic state of Behçet's disease. Thromb Res 1995;80:445-6

15 Newman W, Beall LD, Carson CW, Hunder GG, Graben N, Randhawa ZI, et al. Soluble E-selectin is found in supernatants of activated endothelial cells and is elevated in the serum of patients with septic shock. J Immunol 1993;150: 644-54.

16 Blann AD, Lip GYH. Hypothesis: Is soluble P-selectin a new marker of platelet activation? Atherosclerosis 1997; 128:135-8.

17 Schleiffenbaum B, Spertini O, Tedder TF. Soluble L-selectin is present in human plasma at high levels and retains functional activity. J Cell Biol 1992;119:229-38.

18 Kameda H, Morita I, Handa M, Kaburaki J, Yoshida T, Mimori $\mathrm{T}$, et al. Re-expression of functional P-selectin molecules on the endothelial cell surface by repeated stimulation with thrombin. Br J Haematol 1997;97:34855.

19 Haznedaroglu IC, Özcebe O, Çelik I, Dündar SV, Kirazli S. Haemostatic markers of procoagulant imbalance in Behçet's disease. Eur J Haematol 1996;57:107-8.

20 Cronstein BN, Molad Y, Reibman J, Balakhane E, Levin RI, Weissmann G. Colchicine alters the quantitative and qualitative display of selectins on endothelial cells and neutrophils. J Clin Invest 1995;96:994-1002. 